\title{
A Review of Funding Mechanisms for US Floodplain Buyouts
}

\author{
Kelsey Peterson ${ }^{1}$, Emily Apadula ${ }^{1}$, David Salvesen ${ }^{1}$, Miyuki Hino ${ }^{2}$, Rebecca Kihslinger ${ }^{3}$ \\ and Todd K. BenDor 1,2,*iD \\ 1 Institute for the Environment, University of North Carolina at Chapel Hill, Campus Box \#3140, Chapel Hill, \\ NC 27599, USA; kels9090@live.unc.edu (K.P.); emilyapa@live.unc.edu (E.A.); dsalv@email.unc.edu (D.S.) \\ 2 Department of City and Regional Planning, University of North Carolina at Chapel Hill, Campus Box \#3140, \\ Chapel Hill, NC 27599, USA; mhino@email.unc.edu \\ 3 The Environmental Law Institute, 1730 M St. NW \#700, Washington, DC 20036, USA; kihslinger@eli.org \\ * Correspondence: bendor@unc.edu; Tel.: +1-919962-4760
}

Received: 3 November 2020; Accepted: 25 November 2020; Published: 3 December 2020

check for updates

\begin{abstract}
Increases in extreme weather events have caused extensive flooding across the United States. In response, federal, state, and local governments have broadened their flood mitigation strategies to include acquisition and demolition of flood-damaged homes ("buyouts"). Little work has documented or analyzed the range of strategies for funding buyouts. Federal programs provide the bulk of funding, but these programs are often slow. Also, state and local governments struggle to meet cost-match requirements. We present and analyze a nationwide census of buyout funding programs $(n=34)$, which draw on five primary funding mechanisms. We find that state and local governments are using a range of traditional and innovative financial mechanisms, including municipal/green bonds, revolving loan funds, local option sales taxes, and stormwater utility fees, as viable tools for funding buyouts. These tools may promote more autonomy from federal government mitigation programs, and ultimately, faster buyout processes.
\end{abstract}

Keywords: floodplain buyouts; environmental finance; hazard mitigation; climate adaptation; floodplain management; municipal finance

\section{Introduction}

Over the last 30 years, government-led acquisition and removal of flood-prone residential properties (known as "floodplain buyouts") has become a popular method for reducing future flood damages in the United States [1]. The attraction of buyouts is that they can permanently remove vulnerable homes from flood hazard areas. Buyouts most frequently occur in areas with well-funded local governments that have city planners and resilience officers, as well as the capacity to fund administrative fees [2].

The magnitude of buyout use is frequently limited by the availability of funds [3]. The two main sources of funding for buyouts are federal grant programs administered by the Federal Emergency Management Agency (FEMA) and the US Department of Housing and Urban Development (HUD). However, buyouts funded through these grant programs can take over five years to complete, and funding is only available after a major disaster occurs; most buyouts are reactive rather than proactive [4]. This long time lag, which extends from the flood event that triggered the buyout process to the buyout's completion, can create severe hardships for many homeowners and municipalities [5].

This timing issue with federal programs is exacerbated by acute, post-disaster demand for additional buyout funding, beyond what is federally available [6,7], and beyond expected future buyout demand growth, due to increases in climate-driven hazards [8]. Given the shortcomings of 
the federal grant programs, some local and state governments have begun funding their own buyout programs, drawing on a variety of both established and innovative funding mechanisms. However, little work has comparatively documented the frequency and geography of these programs, the range of funding mechanisms used, or the number of buyouts they implement [3,9]. How are local and state governments funding buyouts? How do their programs interact with available federal funding?

In this paper, we conduct a census (or as close to one as feasible) of buyout funding programs in the United States, documenting the extent of their use and creating a typology of funding mechanisms. We review scholarly literature, news articles, and government documents to describe buyout programs and the unique local, state, and federal funding tools used to implement them. Our findings suggest that state and local governments have access to a variety of financial mechanisms, including municipal bonds, revolving loan funds, local option sales taxes, and stormwater utility fees, which offer pathways for funding buyouts or for meeting the cost-share requirements of federal grant programs.

Understanding the structure and implementation of different financing mechanisms will help state and local governments in multiple ways. First, unlike most federal grants for buyouts, state and local governments can be proactive, acquiring properties before the next disaster occurs. Second, alternative funding mechanisms for the cost-share requirement of federal grants can allow state and local governments to maximize the amount of funding available for acquiring properties and therefore assist as many homeowners as possible.

\section{Background}

\subsection{Federal Buyout Processes}

Recent work by Weber and Moore (2019) [4] documents common, federally-led floodplain buyout processes, whereby state and local governments coordinate with federal agencies-usually either FEMA or HUD-to purchase flood-damaged homes from willing sellers, who receive pre-flood, fair market value for their properties. The majority of buyout funding in the United States is provided through FEMA's Hazard Mitigation Assistance program (HMA), which provides funding for mitigation planning and projects that reduce disaster losses and protect life and property from future disaster damage [10]. The HMA consists of three main programs, (Table 1), including the Hazard Mitigation Grant Program (HMGP), the Pre-Disaster Mitigation Grant Program (PDM; which is being replaced by the Building Resilient Infrastructure and Communities (BRIC) program; [11]), and the Flood Mitigation Assistance Grant Program (FMA; [12]). Under these programs, FEMA has funded over 40,000 buyouts across the United States since the 1980s [2]. It is worth noting that while FEMA-funded buyout programs require participating properties to be located in the 100-year floodplain (the "Special Flood Hazard Area" with a 1\% annual risk of flooding; [13]), many non-FEMA programs do not, making the term "floodplain" buyout sometimes a bit of a misnomer. 
Table 1. Common federal buyout funding mechanisms. "Eligible applicants" identify the organizations able to directly receive funding. Funding is indicated for entire program, not just for buyout purposes. "N/D" = data not readily available, and "NGOs" = non-governmental organizations. PDD = Presidentially Declared Disaster.

\begin{tabular}{|c|c|c|c|c|c|c|c|c|c|}
\hline $\begin{array}{l}\text { Federal } \\
\text { Agency }\end{array}$ & Program Name & $\begin{array}{l}\text { Date Program } \\
\text { Founded }\end{array}$ & Eligible Applicants & $\begin{array}{c}\text { PDD } \\
\text { Requirement }\end{array}$ & $\begin{array}{l}\text { Recent } \\
\text { Funding }\end{array}$ & $\begin{array}{l}\text { Cumulative } \\
\text { Funding }\end{array}$ & $\begin{array}{l}\text { Funding } \\
\text { Source }\end{array}$ & Cost Sharing & Buyouts \\
\hline FEMA & $\begin{array}{l}\text { Hazard } \\
\text { Mitigation Grant } \\
\text { Program (HMGP) }\end{array}$ & 1989 & $\begin{array}{l}\text { Local, state, territorial, } \\
\text { and tribal governments }\end{array}$ & Yes & $\mathrm{N} / \mathrm{D}$ & $\begin{array}{l}\$ 13.8 \text { billion (as of } \\
\text { Feb. 2017) }\end{array}$ & $\begin{array}{l}\text { Post-disaster } \\
\text { appropriation }\end{array}$ & $\begin{array}{l}\text { Non-FEMA: } \\
25 \%\end{array}$ & $>37,000$ \\
\hline FEMA & $\begin{array}{l}\text { Flood Mitigation } \\
\text { Assistance (FMA) } \\
\text { Grant Program }\end{array}$ & 1994 & $\begin{array}{l}\text { Local, state, territorial, } \\
\text { and tribal governments }\end{array}$ & No & $\begin{array}{l}\$ 210 \\
\text { million } \\
(2019)\end{array}$ & $\mathrm{N} / \mathrm{D}$ & $\begin{array}{l}\text { Annual } \\
\text { appropriation }\end{array}$ & $\begin{array}{l}\text { Non-FEMA: } \\
25 \%\end{array}$ & $\mathrm{~N} / \mathrm{D}$ \\
\hline FEMA & $\begin{array}{l}\text { Pre-Disaster } \\
\text { Mitigation (PDM) } \\
\text { Program }\end{array}$ & 1998-2020 & $\begin{array}{l}\text { Local, state, territorial, } \\
\text { and tribal governments }\end{array}$ & No & $\begin{array}{l}\$ 250 \\
\text { million } \\
(2019)\end{array}$ & $\mathrm{N} / \mathrm{D}$ & $\begin{array}{l}\text { Annual } \\
\text { appropriation }\end{array}$ & $\begin{array}{l}\text { Non-FEMA: } \\
25 \%\end{array}$ & $\mathrm{~N} / \mathrm{D}$ \\
\hline FEMA & $\begin{array}{l}\text { Building Resilient } \\
\text { Infrastructure and } \\
\text { Communities } \\
\text { (BRIC) }\end{array}$ & 2020 & $\begin{array}{l}\text { Local, state, territorial, } \\
\text { and tribal governments }\end{array}$ & No & $\begin{array}{l}\$ 500 \\
\text { million } \\
(2020)\end{array}$ & $\mathrm{N} / \mathrm{D}$ & $\begin{array}{l}\text { Annual } \\
\text { appropriations }\end{array}$ & $\begin{array}{l}\text { Non-FEMA: } \\
25 \%\end{array}$ & $\mathrm{~N} / \mathrm{D}$ \\
\hline HUD & $\begin{array}{l}\text { Community } \\
\text { Development } \\
\text { Block } \\
\text { Grant-Disaster } \\
\text { Recovery } \\
\text { (CDBG-DR) }\end{array}$ & 1974 & $\begin{array}{l}\text { State governments, } \\
\text { NGOs, economic } \\
\text { development agencies, } \\
\text { citizens, and businesses }\end{array}$ & Yes & $\mathrm{N} / \mathrm{D}$ & $\$ 89$ billion & $\begin{array}{l}\text { Annual } \\
\text { appropriation }\end{array}$ & $\begin{array}{l}\text { None; often } \\
\text { used to match } \\
\text { other federal } \\
\text { funds. }\end{array}$ & $\mathrm{N} / \mathrm{D}$ \\
\hline
\end{tabular}


Funding from HMA programs may be used for property acquisition and structure demolition or relocation, among other types of mitigation activities [10]. HMA programs typically require a $25 \%$ cost match from eligible applicants including state, local, tribal or territorial governments where buyouts are to occur. Individual home and business owners are unable to directly apply for HMA funds and must instead have an eligible applicant, such as a state, local, or tribal government, apply on their behalf [10].

The largest and longest running of the HMA programs, the Hazard Mitigation Grant Program (HMGP), is used to assist in creating long-term hazard mitigation planning and projects, including buyouts. Studies of the HMGP have shown that for every $\$ 1$ spent, $\$ 4$ of future damages are avoided or mitigated [14]. The HMGP is also the only program under HMA that requires a Presidential major disaster declaration for funding to be made available; FMA and PDM funding depend instead on annual appropriations made by Congress [12]. The FMA grant program is designed to reduce long-term risk of flood damage to structures. Grants under this program are limited to properties insured under FEMA's National Flood Insurance Program (NFIP; [15]).

Finally, the PDM program's goal has been to reduce the risk posed by future natural disasters to people and structures, while also reducing the demand for federal funding in future disasters. The BRIC program pulls an estimated \$300-500 million per year from FEMA's Disaster Relief Fund (instead of using PDM's yearly congressional appropriations, which were more unpredictable; [16]). While BRIC program activities are intended to remain similar to those under PDM, BRIC places a greater emphasis on improving local building codes and incorporating nature-based solutions, as well as training and technical assistance to local governments [16]. Grants may also be used for mitigation planning and projects, including buyouts. Mitigation planning is viewed by FEMA as a key policy tool step for ending the cycle of disaster damage, reconstruction, and repeated damage [17].

Another major federal source of funding for buyouts is provided by HUD's Community Development Block Grant-Disaster Relief (CDBG-DR) appropriation. Like the HMGP, CDBG-DR funding requires a Presidential Declaration of a Disaster in a specific area before funds become available $[14,18]$. Congress may decide to distribute funds to HUD when there are significant unmet needs from other funding sources (e.g., HMGP) for long-term recovery, especially in low-income areas [19]. CDBG-DR funds a wide range of projects, as long as they meet at least one of three national objectives [18,20]: (1) benefit low- and moderate-income persons, (2) help prevent or eliminate slums or blight, and (3) address urgent risks that pose a serious and immediate threat to the health and wealth of the community where other financial resources are unavailable.

Neither individuals nor communities can apply directly for funds. Instead, HUD will notify eligible states, cities, and counties if they are able to receive CDBG-DR funds. These funds cannot duplicate funding made available from other sources, but may be used to match federal resources and may be used in combination with other grants. CDBG-DR funding has often been used to fund buyouts directly or to meet the $25 \%$ match required by HMA funding [19].

\subsection{Impetus for Non-Federal Funding Mechanisms}

While these federal programs provide most of the funding for floodplain buyouts [20], they have also been criticized as being time-consuming, lacking transparency, and not providing sufficient funding to acquire the total number of qualifying properties [4]. For example, the HMGP requirement of a Presidential disaster declaration makes it difficult for local governments to be proactive in acquiring at-risk and repetitive flooded structures prior to floods. This frames floodplain buyouts instead as a reactive tool for mitigating future risk to property and residents.

Weber and Moore (2019) [4] reviewed 30 years of buyouts funded through FEMA, finding a median completion time of approximately five years. This lengthy timeline leaves local governments and residents in limbo during that period. The buyout process can be fraught with uncertainty about application approval and timing. As a result, homeowners often face a difficult decision: wait for possible buyout funding to arrive, rebuild their flood-damaged home, or sell to real estate speculators at a loss [4,21]. 
Limited evidence suggests that local and state governments with their own funding sources can complete buyouts faster than through federal programs, without waiting for a Presidential declaration [4]. An example of this can be seen in the City of Charlotte, North Carolina, where the City created a "Quick Buy" program that purchases properties using funding generated from its stormwater utility fee. Through this program, buyouts can be completed within $\sim 6$ months after a flood event, a significant decrease from the timeframe often seen in federal programs [4,22]. Local programs also provide the flexibility to acquire homes in advance, rather than waiting until after a disaster occurs. Local governments may also be able to be more strategic in how they invest acquisition resources. For example, they may prioritize buyouts in areas where public amenities, such as a park or community garden, are in short supply. In addition, if local governments are paying to acquire flood-damaged homes, they may be more inclined to see the connection between local approval of building in flood hazard areas and the creation of a future liability.

\section{Materials and Methods}

In order to understand the range of techniques that local and state governments (and even non-traditional federal programs) use for funding buyouts, we conducted a census of all programs (at least all those programs that could reasonably be identified through public data sources) that currently fund buyouts in the United States. We sought to document each unique form of funding mechanism (e.g., environmental bonds; stormwater utility fees). We differentiated each of these mechanisms by documenting how they function and the scale of their use (i.e., the number of programs using the mechanism). To do this, we drew on a two-phase process for identifying different mechanisms used to fund buyouts.

We began by reviewing previous efforts to document buyout funding strategies, including work by the Environmental Law Institute [3], which documented a number of novel financing mechanisms, as well as the Natural Resource Defense Council's "Blueprint of a Buyout" article series, which identified buyout projects and their financing mechanisms around the country [22].

Next, we used the Google, Google Scholar, and ProQuest search engines to comb through news articles, blogs, expenditure and other government reports, government announcements, and state and local stormwater management outlets to identify relevant information on buyout projects and programs. Using these engines, we searched by key phrases, including "floodplain buyout," "floodplain acquisition," and "hazard mitigation plan." When we found information about a geographically-specific buyout program, we added that geography or jurisdiction into the search terms for further searches.

Within these news sources and reports were references to buyout plans or mitigation plans (that included buyouts). Within available buyout and mitigation plans was the contact information of professionals involved in buyout or planning processes. We identified missing information not provided in publicly accessible documentation of buyout processes, and contacted these professionals, obtaining information on the progress and status of the programs, scale of their use, adoption date, and current funding status (when available).

Together, these two phases of our search allowed us to identify all (or as many as possible) buyout funding programs at the local and state levels in the United States, as well as to understand the range of funding mechanisms used and whether or not (and how) they interface with federal funding programs.

\section{Results}

We identified 34 separate buyout funding programs, including the five federal programs shown in Table 1, which employ five types of financial mechanisms. As shown in Figure 1, these programs span across 17 municipalities in 17 US states. 




Figure 1. Map of state and local buyout funding programs in the United States. Municipal and county programs are labeled.

On the federal level, we identified a total of nine buyout funding programs, including the HMA and HUD programs discussed earlier (Table 1), as well as one lesser-used program, two now-repealed programs, and one proposed program (Table 2). At the state level, we found six programs using three different financing mechanisms, including grants, revolving loan funds, bonds, and-to some extent-tax credits and incentives. At the local level, we found 19 programs in 17 municipalities using four financing mechanisms, including stormwater utility fees, local option sales taxes, and municipal bonds. Among these state and local funding programs, 88 percent (22 of 25 programs) were aimed (at least in part) at creating a source of local or state funding that could be used as a federal cost-match or otherwise combined with federal funding sources in order to maximize the number of homes acquired.

\subsection{Federal Funding Mechanisms for Floodplain Buyouts}

We begin by summarizing each of the funding mechanisms we identified in our search, starting with the lesser-used federal programs. The USDA's Natural Resource Conservation Service's (NRCS) Emergency Watershed Protection Program-Floodplain Easement (EWP-FPE) program is designed to restore land to its natural condition [23], placing easements on enrolled areas to prevent future damage. Land eligible for these permanent easements include parcels that have been damaged by flooding at least once during the previous calendar year (or twice or more during the previous ten years), that contribute to the restoration of flood water storage and flow, that offer erosion control, that improve the management of floodplain easements, or that would be adversely impacted as a result of a dam breach [23]. 
Table 2. Non-traditional, expired, and proposed federal mechanisms for funding floodplain buyouts. Funding is indicated for an entire program, not just for buyout purposes. N/A = "not applicable.".

\begin{tabular}{|c|c|c|c|c|c|c|c|}
\hline $\begin{array}{c}\text { Federal } \\
\text { Agency/Division }\end{array}$ & Program Title & Year Started & Eligible Applicants & $\begin{array}{c}\text { Funding } \\
\text { Information }\end{array}$ & Cost Sharing & Total Buyouts & Source \\
\hline $\begin{array}{l}\text { USDA Natural } \\
\text { Resources } \\
\text { Conservation } \\
\text { Services (NRCS) }\end{array}$ & $\begin{array}{l}\text { Emergency } \\
\text { Watershed } \\
\text { Protection } \\
\text { Program-Floodplain } \\
\text { Easement } \\
\text { (EWP-FPE) }\end{array}$ & 1996 & $\begin{array}{l}\text { Cities, towns, counties, } \\
\text { conservation districts, or any } \\
\text { federally-recognized Native } \\
\text { American tribe or tribal } \\
\text { organization }\end{array}$ & \$217.5 M (in 2019) & $\begin{array}{l}\text { May cover up to } \\
100 \% \text { cost of the } \\
\text { easement, } \\
\text { structural value or } \\
\text { relocation, } \\
\text { and restoration }\end{array}$ & $\begin{array}{l}1608 \text { easements or } \\
185,137 \text { acres or } \\
\text { enrolled } \\
\text { permanent } \\
\text { easements } \\
\text { (through the end } \\
\text { of 2017) }\end{array}$ & {$[23,24]$} \\
\hline $\begin{array}{l}\text { FEMA National } \\
\text { Flood Insurance } \\
\text { Program (NFIP) }\end{array}$ & $\begin{array}{l}\text { Repetitive Flood } \\
\text { Claims Grant } \\
\text { Program (RFC) }\end{array}$ & 2004-2012 & $\begin{array}{l}\text { Structures insured under the } \\
\text { NFIP that have had one or } \\
\text { more claim payments for } \\
\text { flood damages. }\end{array}$ & $\begin{array}{l}\text { Up to } \$ 10 \mathrm{M} \\
\text { annually }(2008)\end{array}$ & $\begin{array}{l}\text { All grants are } \\
\text { eligible for up to } \\
100 \% \text { cost } \\
\text { assistance }\end{array}$ & $\begin{array}{l}123 \text { properties } \\
(2008-2012)\end{array}$ & {$[25,26]$} \\
\hline FEMA & $\begin{array}{l}\text { Severe Repetitive } \\
\text { Loss Program } \\
(\mathrm{SRL})\end{array}$ & 2004-2012 & $\begin{array}{l}\text { Individuals with } \geq 4 \text { NFIP } \\
\text { claims, payments over } \$ 5000 \\
\text { each, and cumulative amount } \\
\text { of such payments exceeds } \\
\$ 20,000 \text { or two separate claim } \\
\text { payments with cumulative } \\
\text { amount exceeding market } \\
\text { value of building }\end{array}$ & & $\begin{array}{l}100 \% \text { grant funded } \\
\text { up to } \$ 150,000\end{array}$ & $\begin{array}{l}586 \text { properties } \\
(2008-2012)\end{array}$ & {$[27,28]$} \\
\hline $\begin{array}{l}\text { FEMA Revolving } \\
\text { Loan Fund }\end{array}$ & $\begin{array}{l}\text { Resilience } \\
\text { Revolving Loan } \\
\text { Fund Act of } 2019\end{array}$ & $\begin{array}{l}\text { Proposed in } \\
2019\end{array}$ & $\begin{array}{l}\text { State and } \\
\text { federally-recognized tribal } \\
\text { governments }\end{array}$ & $\begin{array}{l}\$ 200 \mathrm{M} \\
(2020-2021)\end{array}$ & $\begin{array}{l}\text { Up to } \$ 100 \mathrm{M} \text { low } \\
\text { interest loan }\end{array}$ & N/A & {$[29,30]$} \\
\hline
\end{tabular}


Some of the restoration efforts under this program have included projects to restore storage of floodwaters, control erosion, improve management of easements, and implement easements in agricultural or residential areas. The latter of these strategies can result in floodplain buyouts, whereby the NRCS pays $100 \%$ of the pre-flood, fair market value for a structure and or property while also paying for the land restoration [23]. In the buyout context, residents volunteering for the program may choose to either demolish or relocate residential structures. Unlike other federal programs, landowners who participate in the EWP-FPE retain their ownership of the land. Landowners are required to provide a permanent conservation easement for the property that prohibits the building of new structures, but they retain the right to quiet enjoyment of the land and to control public access [23].

In the wake of Hurricane Sandy, the National Resource Conservation Service made \$124.8 million available in the EWP-FPE to five affected states. For example, the City of West Haven, Connecticut, received approximately $\$ 7$ million through this program, using some of the funds to purchase 13 homes and restore 34 acres of open space on the easement acquired [31]. More recently, West Haven had additional plans to use a second round of funding to purchase 19 more repetitively flood damaged homes [23,31].

The other federal programs we identified include two repealed programs and one proposed program, both of which reflect mechanisms that we now see at the state and local levels. The former, the Repetitive Flood Claims (RFC) and Severe Repetitive Loss (SRL) grant programs, were created in 2004 to reduce long-term risk to NFIP-insured structures that had filed at least one flood damage claim along with other criteria [25,32]. Although both of these programs were eliminated by the Biggert Waters Flood Insurance Reform Act of 2012 [33], during their operation, funds were used to flood-proof non-residential structures, as well as elevate, acquire and demolish, or relocate residential structures, converting the underlying property to open space [32]. This funding was also used in cases where local governments could otherwise not meet the FMA cost-match requirements or did not have the capacity to manage buyout activities [32].

The latter federal program, which has not yet been approved, is the proposed Resilience Revolving Loan Fund Act of 2019, which has drawn support from a coalition of 80 mayors in eight states along the Mississippi River, after extensive flooding in 2019 [29,30]. If approved, the Act would appropriate \$214 million to FEMA, which would distribute funding to individual states through an application process. States would then administer loans to local governments for resilient infrastructure, including floodplain buyouts for severely damaged structures and those suffering repetitive losses. By devolving implementation of loan funds to states, this program could decrease federal involvement, the complexity of the buyout process, and the time taken to complete buyouts [29].

As we will discuss more in the next section, revolving loan funds are a common tool for federal, state, and local governments to fund long term risk mitigation and meet climate adaptation goals. The initial funding or "capitalization" for this type of loan program normally originates in the form of a grant issued by a federal (in the case of the proposed federal legislation) or state agency [34]. The interest and principal payments from older loans are then used to fund new loans, a strategy called "gap funding." The low interest nature of these loans can facilitate repayment from state and city governments using savings generated by mitigation projects [26,35].

\subsection{State Buyout Funding Programs}

Our review revealed six state-level programs using three mechanisms, including grants, revolving loan funds, and bonds (which we discuss in the next section on local funding programs).

\subsubsection{Grant Programs}

Grant Programs have been used by several state governments to help fund buyout projects. Funding may be granted on an annual or biannual basis to municipalities within a given state and commonly requires some form of cost share with the local government.

An example of a state grant program is Minnesota's Flood Damage Reduction (FDR) Grant Assistance Program, which was created in 1987 to provide both technical and financial assistance 
to local governments [36]. Grants under the FDR program require a 50/50 cost share between the Minnesota Department of Natural Resources and a local government (or federal grant) and typically fund buyouts (acquisition and demolition), relocations, and construction of floodwalls, levees, and other flood mitigation measures.

Under the FDR program, any local government (including conservation and watershed districts) in Minnesota may apply for small or large grants. Small grants $(<\$ 300,000)$ are appropriated by the Minnesota Department of Natural Resources from general funds allocated by the legislature, while large grant $(>\$ 300,000)$ applications must be approved by the Governor and Legislature for consideration in a capital bonding bill.

Similarly, the Wisconsin Municipal Flood Control (WMFC) program offers grants to cities, villages, towns, tribes, and metropolitan sewage districts for a variety of flood mitigation projects. Funds are distributed every other year through Wisconsin general obligation bond revenue and require a $50 \%$ cost match from local governments [37]. Projects include buyouts, as well as efforts to flood-proof homes, restore bodies of water, acquire vacant land, create flood control detention ponds, and develop flood maps. The extent of projects is limited by regulations that no single project may receive a grant equal to more than $20 \%$ of available funds.

The Wisconsin Municipal Flood Control grant program funding can also be used as a match for HMGP and CDBG funding. In 1994, the City of Kenosha created the Fox River Flood Mitigation Program to respond to flood damages along the Fox River in April 1993 [38,39]. Unlike locally funded programs (described in the next section), the Kenosha program drew entirely on WMFC grant funding, alongside HMGP and CDBG grants, to purchase 103 homes on 165 parcels along the Fox River out of a list of 178 "high risk flood locations" [38-40]. While the Fox River Flood Mitigation Program technically still exists, funding from the WMFC program has dwindled, and 20 homes in high risk flood locations remain on a buyout waiting list $[39,40]$.

\subsubsection{Revolving Loan Funds}

Similar to the federally proposed 2019 Resilience Revolving Loan Fund Act, in 2018, the state of South Carolina proposed the "SC Resilient Revolving Loan Fund" (SC SB S.259, 2019-2020) in the aftermath of the unprecedented amount of flooding in the state during Hurricane Florence [41]. The bill was a reaction to the struggles experienced by many coastal counties in providing cost-matching funds for HMGP funding, with much of the financial burden falling on local governments and homeowners. For example, homeowners in Conway, SC were required to pay $25 \%$ of the demolition costs during a buyout and only offered $75 \%$ of the pre-disaster, fair market value of their homes [42].

The proposed revolving loan program would provide funding for the $25 \%$ cost share match that local governments are required to pay when receiving HMA grants from FEMA. By providing the cost share match, this program would relieve the financial barriers to buyout programs for local governments and homeowners, incentivizing participation and expanding the scope of the buyout program. Under the proposed legislation, the state would seek to capitalize the fund with $\$ 2$ million, aiming to secure an additional $\$ 25$ million in CDBG funds in the future [41] (SC SB. 259, 2019-2020).

\subsection{Local Buyout Funding Programs}

We discovered a somewhat different set of buyout funding mechanisms at the local level. These included 19 programs in 17 municipalities covering four different funding mechanisms, including grant programs, stormwater utility fees, local-option sales taxes, and municipal and green bonds. Local financing mechanisms were used in jurisdictions of all sizes, ranging from the City of Bonita Springs, Florida (pop. 50,000), which relies on a stormwater utility fee to fund buyouts, to Harris County, Texas (pop. 4.7 million; encompassing the City of Houston), which recently implemented a large-scale green municipal bond program after Hurricane Harvey.

Likewise, programs are located in communities with a wide range of economic situations, including the Town of Seven Springs, NC, where the $\$ 25,417$ median household $(\mathrm{HH})$ income is less than half 
that of the State of North Carolina, to Nashville, TN, where the $\$ 63,462$ median household income is $\sim 25 \%$ higher than the State of Tennessee's.

\subsubsection{Stormwater Utility Fees}

Municipal permitting requirements established under the US Clean Water Act have incentivized many jurisdictions to establish stormwater utilities [43], whose fees create a dedicated stream of funds to pay for projects necessary to achieve compliance with federal permits [44]. Stormwater utility fees allow municipalities to assign financial responsibility for stormwater-related expenses to property owners. Revenues generated from these fees are used to fund large scale infrastructure projects, as well as to cover utilities' administrative expenses [45]. Some communities assign fees based on the total square footage of impervious surfaces, while others charge a flat fee or tiered fee [44].

Our review identified seven communities-Charlotte-Mecklenburg County, North Carolina; the City of Tulsa, Oklahoma; Nashville, Tennessee; Arlington, Texas; Fort Collins, Colorado; Newport News, Virginia; and Bonita Springs, Florida - that have directed or are intending to direct portions of their stormwater fee revenues to perform buyouts in flood-prone areas. In 1997, Charlotte-Mecklenburg County (encompassing the City of Charlotte; we will refer to as "Charlotte, NC") established a tiered fee based on impervious cover and property use [46]. Through the revenue generated by the fees, the county almost entirely funds its Quick Buy program (mentioned previously), which has acquired over 400 properties, returned 185 acres ( $75 \mathrm{ha})$ of floodplains to open space, and avoided an estimated $\$ 25$ million in damages since 2003 [22].

Similarly, the City of Tulsa established a stormwater utility fee in 1986, which-along with funding other infrastructure- - helps to provide the $25 \%$ cost match required of HMGP funding [47]. Along with municipal bonds and a special purpose local sales tax (defined and discussed in the next section), this program has helped Tulsa remove 900 homes and businesses from floodplains since 1986 . Tulsa imposes a flat fee, meaning every property pays the same amount per month. The fee generates approximately $\$ 9$ million/year and $\$ 70$ million since its conception [46].

The seven different stormwater utility fee programs identified in our census vary in the distribution of resulting revenue, as well as the structure in which the fee is applied. While Charlotte, NC utilizes only $\sim 5.55$ percent of the revenue from its utility fee to conduct floodplain buyouts, this provides up to $\sim \$ 4$ million in funding for buyouts annually through the City's Quick Buy program. Charlotte's use of its fee is unique in that it is the only utility-involved buyout funding program that entirely funds some of its buyout projects (all other utility mechanisms involve some form of federal funding). Charlotte, NC and Newport News, Virginia are the only cities in which a portion of the utility fee is explicitly (under law) dedicated to a buyout program, with Newport News dedicating $\$ 200,000$ for the acquisition, relocation, and elevation of flood-prone structures. Conversely, stormwater utility fee revenue in Arlington, Texas, Ft. Collins, Colorado, and Nashville, Tennessee, was used to address funding needs to match federal dollars after flood events and have no set amount of fee revenue dedicated to buyouts.

\subsubsection{Local Option Sales Taxes}

A local option sales tax (LOST) is a special purpose financial tool used by city and county governments to fund specific categories of projects and financial needs, including buyouts. The small tax, normally ranging from $0.05-2 \%$, must be approved by municipal or county voters before it is added to the established state sales tax [48]. LOSTs currently account for $10 \%$ of all local tax revenue across the country, having been authorized in 33 states [49]. Revenue from a LOST program is collected by the county or municipal government and is typically used to ease reliance on property tax revenue and to bolster municipal general revenue funds [48]. This form of tax carries a "sunset" date, which can be based on a timeframe or amount of revenue generated, and requires renewal legislation by voters or a tax phase out [49]. This funding mechanism represents an important financial tool for local and 
state governments to distribute the funding burden (or federal cost matching) of high cost projects like buyouts across residents.

In 1995, Neosho, Missouri adopted a 3/8ths percent local option sales tax in order to finance a $\$ 1.5$ million municipal bond to fund a number of capital improvement projects, including the purchase of 27 repetitive flood damaged homes, which had not been purchased through a previous buyout funded by the state's Emergency Management Agency, HUD, and NRCS [50]. The sales tax generated \$600,000 annually and was split evenly between parks development, the city's recreation programs, and the buyout project.

In Austin, Minnesota, residents approved a 0.5\% local option sales tax in 2007, aimed at funding flood mitigation projects [51]. Historically, Austin had relied on CDBG-DR and HMGP funds for a majority of its buyout funding, with the Minnesota Department of Natural Resources (MN-DNR) providing the $25 \%$ cost match [20]. However, after creating the LOST, the city has been able to rely on a 50/50 funding split with the MN-DNR for buyout projects, eliminating the need for federal funding [52]. The tax expires in 20 years or once it has reached its $\$ 14$ million cap to obtain bonds which fund proposed flood mitigation projects [53]. The city has bought out 275 structures since its inception and most recently plans on conducting a $\$ 1,000,000$ buyout project between 2017-2021 under this arrangement [52,53].

In contrast to Austin and Neosho, the City of Augusta, Georgia enacted a "Special Purpose" Local Option Sales Tax (or SPLOST), which is unique to the state of Georgia. Established in 1985 by the state of Georgia, SPLOST, in contrast to a LOST, is a county tax which can only be enacted through a local referendum [54]. In addition, SPLOST revenue can only be used for capital outlay projects, meaning the funding cannot be used for operation and maintenance cost or for any other county or municipal facility or service. Augusta-Richmond County established its 1 percent SPLOST in 2004 which has been renewed by voters seven times to date [55]. On the fifth renewal of the SPLOST, revenue from the tax was used to acquire 19 flood prone properties between 2012-2015 without utilizing federal funding.

\subsubsection{Municipal and Green Bonds}

A municipal bond is a low risk investment vehicle whereby an investor (bond holder) loans money to a government (bond issuer) in order to receive scheduled interest payments over time as well as the principal (face value) of the bond at the end of the bond term [56]. Municipal bonds are debt securities issued by states, cities, counties, or other governmental entities [57]. Bonds give the state or local government access to funding sufficient to implement projects that require large sums of capital, such as floodplain buyouts. Our review reveals that revenues from municipal and state issued bonds are normally used as leverage for federal dollars in order to maximize the scale of buyouts [3]. These bonds carry a low default risk and the interest payments to bond holders are normally tax exempt [58].

When a floodplain buyout program utilizes a municipal or state bond, it can earn the title of a "green bond," which is increasingly being used to market and fund resilient infrastructure. The term "green bond" suggests a bond that is directed towards a net positive environmental impact [59]. This net positive environmental impact is a result of green infrastructure, including infrastructure improvements in the water, buildings and industry, energy, land conservation, power, transport, and waste and pollution sectors [60]. The market for green municipal bonds has been growing ever since the first was issued in Europe in 2007 [59]. In 2018, the collective par (face) value of the municipal green bond market was $\$ 4.9$ billion [61], and cumulative global issuance (bond demand) was estimated at $\$ 521$ billion, with the U.S. leading the market with $\$ 118$ billion issuances ( $20 \%$ of the global market; [62]).

However, due to the relatively recent development of green bonds, there is no single standard or certification process to obtain the label. There are a number of independent organizations that offer backing to a green bond label such as the Climate Bonds Initiative's certification scheme and CICERO, an organization that offers second opinions on green bond labeling that are beginning to set the standard for transparency and definition within the market [63].

Green municipal bonds have been used to fund floodplain buyouts by local governments in Harris County, Texas and the City of Tulsa, Oklahoma, as well as the State of New Jersey. Harris County, Texas voters approved a historic \$2.5 billion green bond program in 2018 after Hurricane Harvey 
flooded over 200,000 homes and apartments [64]. Drawing \$59 million in bond funds as cost-match leverage to obtain $\$ 159$ million from the HMGP, Harris County plans on purchasing approximately 900 properties [65]. On a smaller scale, the City of Tulsa, Oklahoma uses a municipal green bond program created in the wake of a historic 1984 rainfall. Since then, the bond program has been used in conjunction with a special purpose local option sales tax, HMGP, and CDBG funding for buyout projects, including $\$ 1,300,000$ for voluntary buyouts for fiscal year 2019-2020 [66].

In New Jersey, the State's Blue/Green Acres program is partially funded by bonds, which have generated \$36 million to be used as leverage for HMGP and CDBG funding for the acquisition of 700 properties and structures as of 2019 (NJ Department of Environmental Protection, 2020; [67]).

\subsection{The Extent of Local and State Buyout Programs}

At the state level, we identified six state funding programs that have been used to help acquire $\sim 5700$ properties or structures (see Table 3) between 1976 and 2020 (this period reflects the start of the earliest state grant program). Within state programs where funding for buyouts was specified (Maryland's program only), we found an estimated \$8 million in appropriations. Within programs where we were unable to distinguish financial expenditures on buyouts, we found an additional $\sim 735$ million in state appropriations for flood mitigation measures, generally.

At the local level, we identified 19 programs in 17 municipalities that bought out $\sim 3900$ properties or structures between 1986 (when Tulsa, Oklahoma's flood mitigation program began) and 2020 using one or more of the four types of local funding mechanisms described in Table 3. Within local programs where funding for buyouts was specified, we found an estimated $\sim \$ 7.6$ million in appropriations corresponding to 448 buyouts. Within local programs where we were unable to separate the financial expenditures on buyouts from other flood mitigation measures, local governments appropriated $\sim \$ 411$ million corresponding to an additional 3435 buyouts. 
Table 3. State and local buyout programs by funding mechanism. Total buyouts reported in terms of properties or structures.

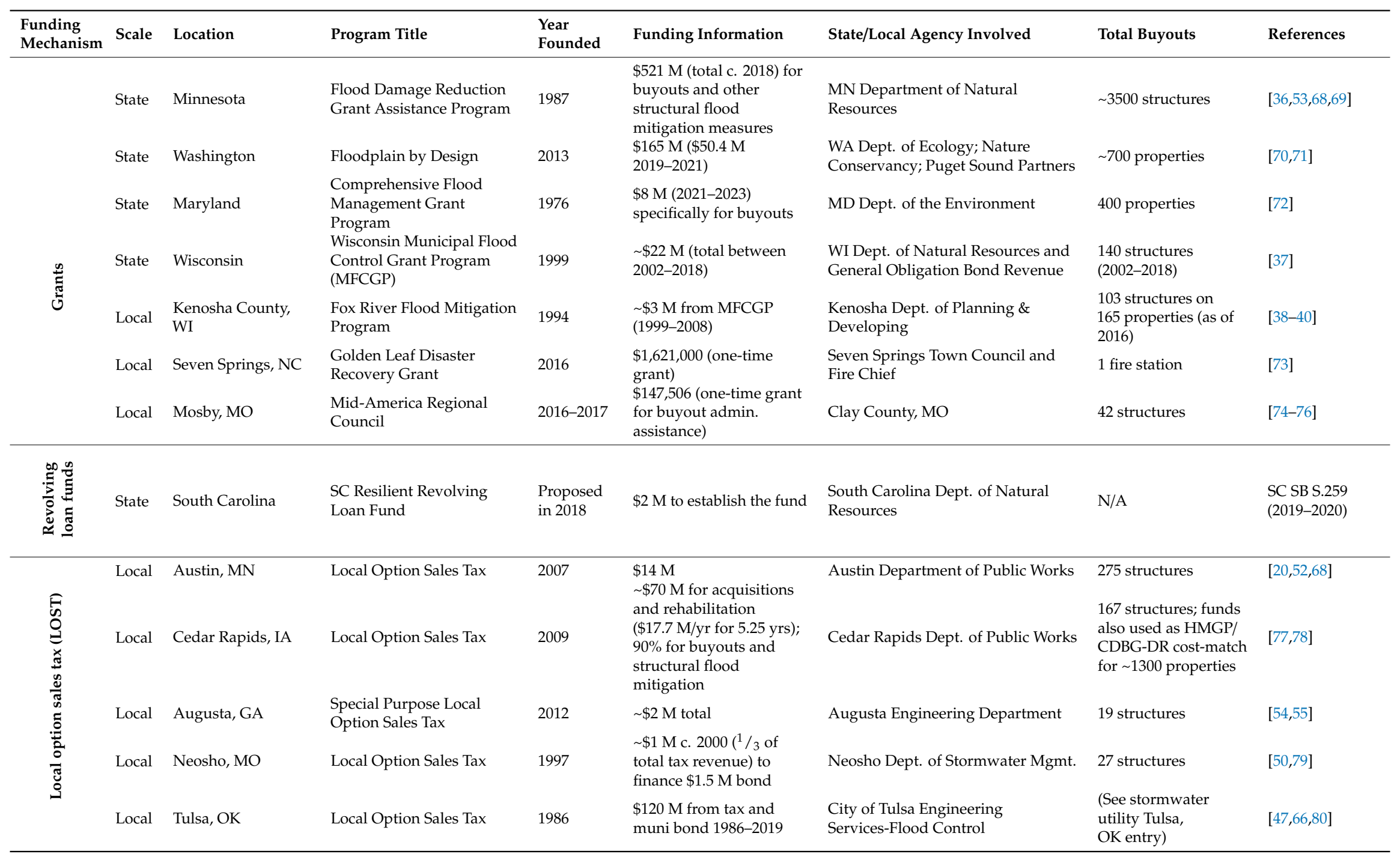


Table 3. Cont






\section{Discussion and Conclusions}

This census of funding mechanisms demonstrates the prevalence and variety of state and local tools used to augment federal financing of floodplain buyouts. In sum, state and local funding programs have resulted in the purchase of some $\sim 9600$ flood-prone properties or structures. As most of these buyouts occur with funding from programs that share costs with FEMA, they represent nearly $25 \%$ of the over 40,000 total properties acquired with federal grants.

Half of the operating state and local funding programs (11 of 22) were established after 2006, with five being established since 2016. This recent trend towards program establishment suggests that many communities both recognize the value of floodplain acquisitions and are willing to invest in expanding their reach. For example, in using its stormwater utility fee to cost-match nearly $\$ 900,000$ of HMGP funds, Arlington, TX observed that

Acquisition of these homes will remove flood prone structures from the floodway and floodplain, thereby eliminating future damages and health and safety risks for those homeowners... This includes eliminating the need to provide emergency response services, subsidized flood insurance, and future federal disaster assistance [90].

Going forward, as state and local programs continue to emerge and evolve, they can address some of the shortcomings of federally-funded buyouts identified here, namely: funding, flexibility and uncertainty. First, the inability to provide the local contribution for federal funds can discourage local governments from participating in a buyout. At least one state, South Carolina, attempted to address this through its proposed Resilient Revolving Loan Fund (SC SB S.259, 2019-2020). State and local programs offer one path for streamlining cost matches to obtain federal funds.

Second, programs that are funded independently of federal programs can operate with more flexibility, buying homes more quickly than through federal programs: for example, six months in Charlotte versus five years for federally-funded buyouts [22]. Moreover, state and local governments can be proactive in acquiring flood-prone homes, rather than acting after-the-fact, as with federal grants. Also, as Weber and Moore (2019) [4] pointed out, state and local funding programs can be more flexible in their application of buyouts. For example, a local government could target an entire neighborhood for acquisition, even including homes that would not meet the federal government's cost/benefit criteria. In short, state- and locally-funded buyouts can be faster and more flexible than federal programs and can be proactive, rather than reactive.

Third, state and local buyout programs can reduce the complexity and uncertainty of federal programs; specifically, they can add certainty as to the timing and amount of funding availability, as well as which homes will be eligible. However, the extent to which these non-federal funding sources systematically increase the number of properties bought and reduce the timeline of buyout projects, are areas in need of further investigation. Additional research is needed to evaluate the relative cost-efficiency of state and local programs compared to federally funded programs. Such research is particularly timely given the projected increased changes in sea level and in the intensity of storms and frequency of flooding, which may increase the demand for buyouts.

Our analysis suggests possibilities for improving the interface between federal and state/local buyout funding programs. As buyout financing strategies continue to evolve, monitoring and evaluation of federal programs can help ensure equitable access to buyouts across communities of different size, wealth, and geography. For example, recognizing that the $25 \%$ cost-share can inhibit access to federal funds, existing federal programs could add flexibility to (or reduce or eliminate) the cost-share requirement for small and impoverished communities (e.g., BRIC allows cost shares of only $10 \%$ in these cases; [11]). While our analysis does not indicate a link between community wealth and program establishment, it is possible that increased self-financing of buyouts by states and municipalities could eventually lead to disparities in the communities that are able to access federal funds; smaller and lower-income communities might find it more difficult to impose a new sales tax or issue a bond, remaining heavily reliant on federal funds, but with limited local matching funds. 
Additional research investigating the geographic, socioeconomic, and political drivers of use of these non-federal buyout funding mechanisms could also inform these concerns.

While our analysis can inform communities interested in exploring alternative funding for buyouts, the suitability of bonds, stormwater utility fees, or local taxes will depend on local context. Like any infrastructure program, communities inevitably vary in their ability to generate funds for buyouts and in their capacity to administer a buyout program. State and local governments might also consider using tax incentives and credits to promote buyouts. Tax incentives and credits have been used to motivate conservation programs. For example, the Arkansas Wetland and Riparian Zone Creation, Restoration, and Conservation Tax Credits Act (1995) grants a state income tax credit to taxpayers who develop, restore, or conserve wetland and riparian zones [99]. Qualifying activities include establishing permanent vegetation, stabilizing stream banks and controlling erosion, and installing water control structures. To our knowledge, such mechanisms have not yet been used explicitly in the context of floodplain acquisitions.

Author Contributions: Conceptualization, M.H., T.K.B., and D.S.; methodology, M.H., D.S., and T.K.B.; formal analysis, data curation, and writing-original draft, K.P. and E.A.; writing-review and editing, M.H., R.K., T.K.B., D.S., E.A., and K.P.; visualization, T.K.B.; supervision, T.K.B. and D.S.; project administration, T.K.B.; funding acquisition, T.K.B. and D.S. All authors have read and agreed to the published version of the manuscript.

Funding: This research was funded by the University of North Carolina Policy Collaboratory, as well as by the U.S. National Science Foundation under Coastal SEES Grant No. 1427188 and Geography and Spatial Sciences Grant No. 1660450.

Acknowledgments: We would like to thank the local and state officials that provided information about the buying funding programs documented in this manuscript.

Conflicts of Interest: The authors declare no conflict of interest. The funders had no role in the design of the study; in the collection, analyses, or interpretation of data; in the writing of the manuscript, or in the decision to publish the results.

\section{References}

1. Patterson, G. Case Studies in Floodplain Buyouts; Rice University Kinder Institute for Urban Research: Houston, TX, USA, 2018. [CrossRef]

2. Mach, K.J.; Kraan, C.M.; Hino, M.; Siders, A.; Johnston, E.M.; Field, C.B. Managed retreat through voluntary buyouts of flood-prone properties. Sci. Adv. 2019, 5, eaax8995. [CrossRef] [PubMed]

3. Kihslinger, R.; Moraga-Lewy, N. Financing and Incentivizing Floodplain Buyouts: A Guide; Environmental Law Institute: Washington, DC, USA, 2017.

4. Weber, A.; Moore, R. Going Under: Long Wait Times for Post-Flood Buyouts Leave Homeowners Underwater; Natural Resource Defense Council: New York City, NY, USA, 2019.

5. Mulvihill, K. How Long Does It Take to Get a FEMA Buyout for a Flooded Home? Natural Resource Defense Council: New York City, NY, USA, 2019.

6. Song, L.; Shaw, A.; Satija, N. Buyouts Won't Be the Answer for Many Frequent Flooding Victims. Available online: https://features.propublica.org/houston-buyouts/hurricane-harvey-home-buyouts-harris-county/ (accessed on 18 August 2020).

7. Painter, W.L. The Disaster Relief Fund: Overview and Issues; Congressional Research Service: Washington, DC, USA, 2019.

8. World Resources Institute. New Data Shows Millions of People, Trillions in Property at Risk from Flooding - But Infrastructure Investments Now Can Significantly Lower Flood Risk. Available online: https://www.wri.org/news/2020/04/release-new-data-shows-millions-people-trillionsproperty-risk-flooding-infrastructure (accessed on 27 September 2020).

9. Bendor, T.K.; Salvesen, D.; Kamrath, C.; Ganser, B. Floodplain Buyouts and Municipal Finance. Nat. Hazards Rev. 2020, 21, 04020020. [CrossRef]

10. Federal Emergency Management Agency. Hazard Mitigation Assistance; Federal Emergency Management Agency: Washington, DC, USA, 2020.

11. Federal Emergency Management Agency. Building Resilient Infrastructure and Communities (BRIC); Federal Emergency Management Agency: Washington, DC, USA, 2020. 
12. Federal Emergency Management Agency. Flood Mitigation Assistance Grant Program; Federal Emergency Management Agency: Washington, DC, USA, 2020.

13. Federal Emergency Management Agency. Flood Zones. Available online: https://www.fema.gov/glossary/ flood-zones (accessed on 3 November 2020).

14. Federal Emergency Management Agency. Hazard Mitigation Grant Program; Federal Emergency Management Agency: Washington, DC, USA, 2019.

15. Federal Emergency Management Agency. National Flood Insurance Program; Federal Emergency Management Association: Washington, DC, USA, 2019.

16. Holdeman, E. BRIC Expanding the Concepts of Federal Pre-Disaster Mitigation; e.Republic: Folsom, CA, USA, 2019.

17. Federal Emergency Management Agency. Pre-Disaster Mitigation Grant Program; Federal Emergency Management Agency: Washington, DC, USA, 2019.

18. U.S. Department of Housing and Urban Development. Fact Sheet: Community Development Block Grant Disaster Recovery; U.S. Department of Housing and Urban Development: Washington, DC, USA, 2020.

19. U.S. Department of Housing and Urban Development. CDBG-DR: Community Development Block Grant Disaster Recovery Program; U.S. Department of Housing and Urban Development: Washington, DC, USA, 2020.

20. Kihslinger, R.; Salvesen, D. Floodplain Buyouts: An Action Guide for Local Governments on How to Maximize Community Benefits, Habitat Connectivity, and Resilience; Environmental Law Institute: Washington, DC, USA, 2017.

21. Bubenik, T. As Post-Harvey Buyout Money Rolls in, Some Have Already Given up on the Program; University of Houston: Houston, TX, USA, 2018.

22. Weber, A. Blueprint of a Buyout: Charlotte/Mecklenburg County, NC; Natural Resources Defense Council: New York City, NY, USA, 2019.

23. Natural Resource Conservation Service. EWP Floodplain Easement Program-Floodplain Easement Option (EWPP-FPE); USDA Natural Resource Conservation Service: Washington, DC, USA, 2020.

24. Clayton, C. NCRS Offers to Buy Conservation Easements in Flooded Areas; Progressive Farmer DTN: Birmingham, AL, USA, 2019.

25. Georgetown Climate Center. FEMA Repetitive Flood Claims Program; Georgetown Climate Center: Washington DC, USA, 2011.

26. Federal Emergency Management Agency. Repetitive Flood Claims Program; Federal Emergency Management Agency: Washington, DC, USA, 2018.

27. Federal Emergency Management Agency. Guidance for Severe Repetitive Loss Properties; Federal Emergency Management Agency: Washington, DC, USA, 2014.

28. Homeland Security Grants. Severe Repetitive Loss (SRL) Grant Program; Homeland Security Grants: Rochester, NY, USA, 2012.

29. Lopez, A. Resilience Revolving Loan Fund Helps Cities and States Prepare for the Future Now; American Society of Civil Engineers: Reston, VA, USA, 2019.

30. Yoders, J. House Bill Would Create $\$ 100 M$ Disaster-Aid Revolving Loan Fund; Engineering News Record Midwest: Troy, MI, USA, 2019.

31. New Haven Register. 13 Flood-Prone Homes in West Haven to Be Demolished; New Haven Register: New Haven, CT, USA, 2016.

32. Public Safety Grants. Repetitive Flood Claims (RFC) Grant Program; Public Safety Grants: Rochester, NY, USA, 2018.

33. Federal Emergency Management Agency. Questions about the Biggert-Waters Flood Insurance Reform Act of 2012; Federal Emergency Management Agency: Washington DC, WA, USA, 2012.

34. Council of Development Finance Agencies. Revolving Loan Funds \& Development Finance; Council of Development Finance Agencies: Columbus, OH, USA, 2020.

35. Lightbody, L.; Fuchs, M. Every \$1 Invested in Disaster Mitigation Saves \$6; The PEW Charitable Trusts: Philadelphia, PA, USA, 2018.

36. Lynch, P. Flood Damage Reduction Grant Assistance Program; Minnesota Department of Natural Resources: Saint Paul, MN, USA, 2012.

37. Fuchs, M. Wisconsin Grant Program Helps People Relocate from Flood-Prone Areas; The PEW Charitable Trusts: Philadelphia, PA, USA, 2019. 
38. City of Kenosha. Fox River Flood Mitigation Program; Kenosha Department of Planning and Development: Kenosha, WI, USA, 2014.

39. Federal Emergency Management Agency. Moving People out of Harm's Way Full Mitigation Best Practice Story Kenosha County, Wisconsin; Federal Emergency Management Agency: Washington, DC, USA, 2010.

40. Salvesen, D.; Kihslinger, R. Case Study: Kenosha, Wisconsin; Environmental Law Institute: Washington, DC, USA, 2016.

41. Johnson, C. Proposed State Fund Would Help Facilitate Flood Buyouts in SC; Post and Courier: Charleston, SC, USA, 2020.

42. Kummerer, S. It's Your Money: Conway Plans to Buy More than 40 Homes to Prevent Future Flooding; A Gray Media Group: Myrtle Beach, SC, USA, 2019.

43. Stormwater Phase II Final Rule Fact Sheet Series; Environmental Protection Agency: Washington, DC, USA, 2018.

44. Kirk, E.; Hughes, J. Stormwater Fees and Fee Structures in North Carolina as of July 2018; North Carolina Department of Environmental Quality: Raleigh, NC, USA, 2019.

45. Zhao, J.Z.; Fonseca, C.; Zeerak, R. Stormwater Utility Fees and Credits: A Funding Strategy for Sustainability. Sustainability 2019, 11, 1913. [CrossRef]

46. City of Charlotte. Current Storm Water Services Fees; Charlotte-Mecklenburg Storm Water Services: Charlotte, NC, USA, 2020.

47. Naturally Resilient Communities Mingo Creek, Tulsa, Oklahoma. Available online: http://nrcsolutions.org/ tulsa-oklahoma/ (accessed on 21 June 2020).

48. Worsham, P.C. North Carolina Local Option Sales and Use Taxes; North Carolina Association of County Commissioners: Raleigh, NC, USA, 2020.

49. Green, A.D. County Governments and Democratic Decision Making: Explaining Why Counties Seek Approval of Local Option Sales Taxes. State Politics Policy Q. 2014, 14, 50-71. [CrossRef]

50. Federal Emergency Management Agency. Success Stories from the Missouri Buyout Program; Federal Emergency Management Agency: Washington, DC, USA, 2002.

51. Dalton, P. Local Sales Taxes in Minnesota; Minnesota House of Representatives: Saint Paul, MN, USA, 2016.

52. City of Austin. 5-Year Capital Improvement Plan 2017-2021; City of Austin: Austin, MN, USA, 2016.

53. Minnesota Department of Natural Resources. Minnesota's Flood Hazard Mitigation Grant Assistance Program Helping Build Community Resiliency Since 1987; Minnesota Department of Natural Resources: Saint Paul, MN, USA, 2018.

54. Association County Commissioners of Georgia. Special Purpose Local Option Sales Tax: A Guide for County Officials; Association County Commissioners of Georgia: Atlanta, GA, USA, 2016.

55. City of Augusta. Floodplain Management; Augusta Department of Planning and Zoning: Augusta, GA, USA, 2016.

56. Karpf, A.; Mandel, A. The changing value of the 'green' label on the US municipal bond market. Nat. Clim. Chang. 2018, 8, 161-165. [CrossRef]

57. Tax Policy Center. What Are Municipal Bonds and How Are They Used? Urban Institute and Brookings Institute: Washington, DC, USA, 2020.

58. Aleksandrova-Zlatanska, S.; Kalcheva, D.Z. Alternatives for Financing of Municipal Investments-Green Bonds. Rev. Econ. Bus. Stud. 2019, 12, 57-77. [CrossRef]

59. Marin, C.; Bredson, A.; Ramchandani, A.; Forsgren, K.; Groce, N. 2018 U.S. Municipal Green Bond E Resiliency Outlook; Standard and Poor's Financial Services: New York City, NY, USA, 2018.

60. Forsgren, K. What's Next for U.S. Municipal Green Bonds? Standard and Poor Global: New York, NY, USA, 2016.

61. Burke, E.B.; Bredeson, A. U.S. Municipal Green Bond and Resiliency Outlook: Will The Self-Labeled Market Rebound? Standard and Poor Global: New York City, NY, USA, 2019.

62. Climate Bonds Initiative. Green Bonds: The State of the Market; Climate Bonds Initiative: London, UK, 2018.

63. Chaudhary, S. Look for the Green Bond Label? The State of Green Bond Certification; Conservation Finance Network: New Haven, Connecticut, CT, USA, 2020.

64. Despart, Z. With Bond Funds Secured, Harris County Ramps up Floodplain Buyouts; Houston Chronicle: Houston, TX, USA, 2019.

65. Anchondo, C. Report: Harris County Buyouts of Flooded Homes Have Been Less than Strategic; The Texas Tribune: Austin, TX, USA, 2019. 
66. City of Tulsa. Annual Budget and Capital Plan: Fiscal Year 2018-2019; City of Tulsa: Tulsa, OK, USA, 2017.

67. Hajna, L.; Shinske, C. Department of Environmental Protection's Blue Acres Program Marks Milestone with 700th Purchase; State of New Jersey Department of Environmental Protection: Trenton, NJ, USA, 2019.

68. Minnesota Department of Natural Resources. Flood Hazard Mitigation; Minnesota Department of Natural Resources: Saint Paul, MN, USA, 2020.

69. Minnesota Department of Natural Resources. Guidebook: Flood Damage Reduction Grant Assistance Program; Minnesota Department of Natural Resources: Saint Paul, MN, USA, 2016.

70. Brown, A. Washington State Experiments with Buyouts, Restoring Floodplains to Avoid Future Disasters. Available online: https://phys.org/news/2019-10-washington-state-buyouts-floodplains-future. html (accessed on 27 June 2020).

71. McKinney, S. Floodplains by Design; Washington State Department of Ecology: Bellevue, WA, USA, 2019.

72. Maryland Department of the Environment. Comprehensive Flood Management Grant Program; Maryland Department of the Environment: Baltimore, MD, USA, 2020.

73. UNC Coastal Resilience Center. 2018 Seven Springs Recovery Plan; Coastal Resilience Center: Chapel Hill, NC, USA, 2018.

74. Lieb, D. Flood Buyouts Upend Missouri Town; Northwest Arkansas Democrat Gazette: Fayetteville, AR, USA, 2019.

75. Clay County. Floodplain Management; Clay County Planning and Zoning: Liberty, MO, USA, 2020.

76. Mid-American Regional Council. Overview-Small Cities Program; Mid-American Regional Council: Kansas City, MO, USA, 2020.

77. U.S. Army Corps of Engineers. Cedar River Cedar Rapids, Iowa Flood Risk Management Project; U.S. Army Corps of Engineers: Rock Island, IL, USA, 2011.

78. Smith, R. Cedar Rapids Flood Buyout Is History; The Gazette: Cedar Rapids, IA, USA, 2014.

79. FEMA. Partnership, Program, Persistence Watershed Buyout Plan. FEMA.gov. Available online: https: //www.fema.gov/node/454223 (accessed on 2 November 2020).

80. Rohmer, A. After the Flood: Exercising Best Practices in Property Acquisition Programs and Open Space Projects; City and Regional Planning Department UNC-CH: Chapel Hill, NC, USA, 2017.

81. State of New Jersey Department of Environmental Protection. Green Acres Funding Summary 1961-2014; State of New Jersey Department of Environmental Protection: Trenton, NJ, USA, 2019.

82. Coutu, P. Virginia Beach to Consider $\$ 430$ Million Bond Referendum in Effort to Speed up Flood Control Projects; The Virginia Pilot: Norfolk, VA, USA, 2020.

83. Sallinger, B. Regional Greenspace Bond Measures: Three Decades of Protecting Nature Close to Home; Portland Audubon: Portland, OR, USA, 2019.

84. City of Portland. Johnson Creek Land Acquisition Partnership and Implementation Strategy; Portland Bureau of Planning: Portland, OR, USA, 2020.

85. Love, D. Floodplain Buyout (Acquisition) Program; Charlotte-Mecklenburg Storm Water Services: Charlotte, NC, USA, 2020.

86. Mulcahy, A. Nashville Home Buyout Program: An Analysis; ArcGIS StoryMaps: Redlands, CA, USA, 2019.

87. Shapiro, M. Study Finds that Proactive Home Buyouts Provide Financial Benefits, Reduce Flood Damage, and Protect Homeowners; Science X: Isle of Man, UK, 2020.

88. City of Nashville. Nashville Stormwater Fees. Available online: https://www.nashville.gov/Water-Services/ Stormwater/Stormwater-Fee.aspx (accessed on 27 September 2020).

89. Spillyards, A. Arlington Buys Out Flood Damaged Residents. Available online: https://www.nbcdfw.com/ local/arlington-buys-out-flood-damaged-residents/264501/ (accessed on 27 June 2020).

90. City of Arlington. Arlington Receives $\$ 879,000$ Federal Grant to Reduce Home Flooding; City of Arlington Office of Communication: Arlington, TX, USA, 2016.

91. Clift, T. It's in Newport News' Budget: \$200,000 for Flood Assistance Program; Daily Press: Newport News, VA, USA, 2015.

92. Editorial. Flooded with Challenges; Hampton Roads Daily Press: Hampton Roads, VA, USA, 2018.

93. City of Newport News. Flood Assistance Program; Newport News Stormwater Management: Newport News, VA, USA, 2020.

94. City of Newport News. Southeast Community Plan; Newport News Department of Planning: Newport News, VA, USA, 2011. 
95. Mast, T. Bonita Springs Stormwater Fee Approved by City Council for Flood Prevention; Naples Daily New: Naples, FL, USA, 2019.

96. City of Bonita Springs. Quinn/Downs Area Parcel Acquisition Voluntary Buyout Program; City of Bonita Springs: Bonita Springs, FL, USA, 2019.

97. Colorado Division of Homeland Security and Emergency Management. Flood Mitigation in Fort Collins, Colorado; Colorado Division of Homeland Security and Emergency Management: Centennial, CO, USA, 2019.

98. City of Tulsa. Stormwater Fee and Funding; City of Tulsa: Tulsa, OK, USA, 2020.

99. Arkansas Department of Agriculture. Wetlands \& Riparian Zone Tax Credit Program; Arkansas Department of Agriculture: Little Rock, AR, USA, 2013.

Publisher's Note: MDPI stays neutral with regard to jurisdictional claims in published maps and institutional affiliations.

(C) 2020 by the authors. Licensee MDPI, Basel, Switzerland. This article is an open access article distributed under the terms and conditions of the Creative Commons Attribution (CC BY) license (http://creativecommons.org/licenses/by/4.0/). 